\title{
Species of Camarosporium on Forest Trees and Shrubs New Reports from Anatolian Peninsula
}

\author{
Elsad Huseyin $^{1 *}$, Faruk Selcuk ${ }^{1}$, Hasan Akgul ${ }^{2}$ \\ ${ }^{1}$ Ahi Evran University, Arts and Sciences Faculty, Department of Biology. Kirşehir/ TURKEY \\ ${ }^{2}$ Akdeniz University, Sciences Faculty, Department of Biology. Antalya/ TURKEY
}

\begin{abstract}
During a diversity survey of dendrocolous fungi in Kirşehir Province of Turkey, many coelomycete specimens were collected in 2012-2014. Among them six new records of Camarosporium species from Anatolian Peninsula are reported here. They are Camarosporium astragalinum, C. cruciatum, C. kirchneri, C. multiforme, C. polymorphum and C. ulmi. The brief description and illustration of microscopic characters are provided for these taxa based on Turkish specimens.
\end{abstract}

Keywords: Ascomycota, biodiversity, anamorphic fungi, taxonomy.

\section{INTRODUCTION}

The genus Camarosporium was introduced by Schulzer [1] with C. quaternatum Schulzer as the type species. Currently, there are more than 500 names listed in the genus [2]. Members of Camarosporium ssp. have a world wide distribution and commonly inhabit branches and leaves as saprobes of a wide range of hosts [3, 4]. Zachos et al. [5] and Holevas et al. [6] have reported that $C$. pistaciae Zachos, Tzav.-Klon. \& Roubosis a fungal plant pathogen that causes blight in pistachio shoots and panicles. Hüseyinov [7] and Hüseyin \& Yıldızbaş [8] noted Camarosporium kursanovii Mekht. and C. oreades (Durieu \& Mont.) Sacc. as causative agents of leaf spots on Quercus macranthera, and Taylor et al. [9] reported on Camarosporium species associated with leaf spots of Protea cynaroides, but all authors suggested that they were not economically important phytopathogens, except $C$. pistaciae.

Camarosporium is a large coelomycetous genus which was formerly recognised as an asexual state in Botryosphaeriales and Cucurbitariaceae. Molecular studies on the phylogenetic placement of the genus and species of Camarosporium have been carried out by Wijayawardene et al. $[10,11]$ and Crous \& Groenwald [12] and showed that Camarosporium sensu stricto to Pleosporinae (Pleosporales).

During our collection of coelomycetes in Kurşehir Province of Turkey, we collected several Camarosporium-like species and carried out morphological studies. In this study we report on morphological data analyses of collected samples and seven taxa that show them to belong to new records.

New Camarosporium species registered in Boztepe district of Kırşehir province of Turkey. The Boztepe district situated in the central Kizllirmak section of the Anatolian Peninsula. The geographical coordinates of the studied area are $39^{\circ} 11^{\prime}-39^{\circ} 27^{\prime} \mathrm{N}, 34^{\circ} 12^{\prime}-34^{\circ} 36^{\prime} \mathrm{E}$ and take place entirely in the Irano-Turanian phytogeographic region [13]. On the northern and north-eastern dry stream beds forest-steppe plant formations are common. Microclimate has been created by these areas for the Euro-Siberian and Mediterranean elements. According to the grid square system adopted by Davis [14] Boztepe district is located in the square B5.

\section{MATERIAL AND MeThodS}

Specimens of the fungi were collected during periodical mycological excursions all in Boztepe district, Kırşehir Province, in 2012-2014. Microscopic studies were carried out on slides prepared in distilled water. Microphotographs were captured by Olympus BX 53 research microscope supplied with Olympus DP 22 digi-CAM (Japan) and Axio imager 2 equipped with Nomarski differential 
interference contrast optics. Species were identified by consulting handbooks and other publications $[3,15,16,17,18,19,20,21,22,23,24]$. The host plants were identified using "Flora of Turkey and East Aegean Islands" [14]. Taxa, families, and author citations are spelled according to Kirk \& Ansell [25], and Index Fungorum [2]. All specimens are deposited in the Mycological Collection of the Ahi Evran University, Kırşehir (Arts and Sciences Faculty, Department of Biology).

\section{RESULTS AND DiSCUSSION}

\section{Taxonomy}

\section{Incertae Sedis}

\section{Anamorphic Pleosporales}

Camarosporium astragalinum Sacc. \& Trotter, Syll. fung. (Abellini) 22: 1078 (1913). Fig. 1.

Saprobic o n dead stems of Astragalus asciocalyx. Sexual Morph: Undetermined.

Asexual Morph: Conidiomata 450-500 $\mu \mathrm{m}$ diam. pycnidial, immersed, erumpent, solitary or in little groups, globose, subglobose, black, papillate. Conidia (12.5-) 15-17 × (5-)6-7 $\mu \mathrm{m}$,

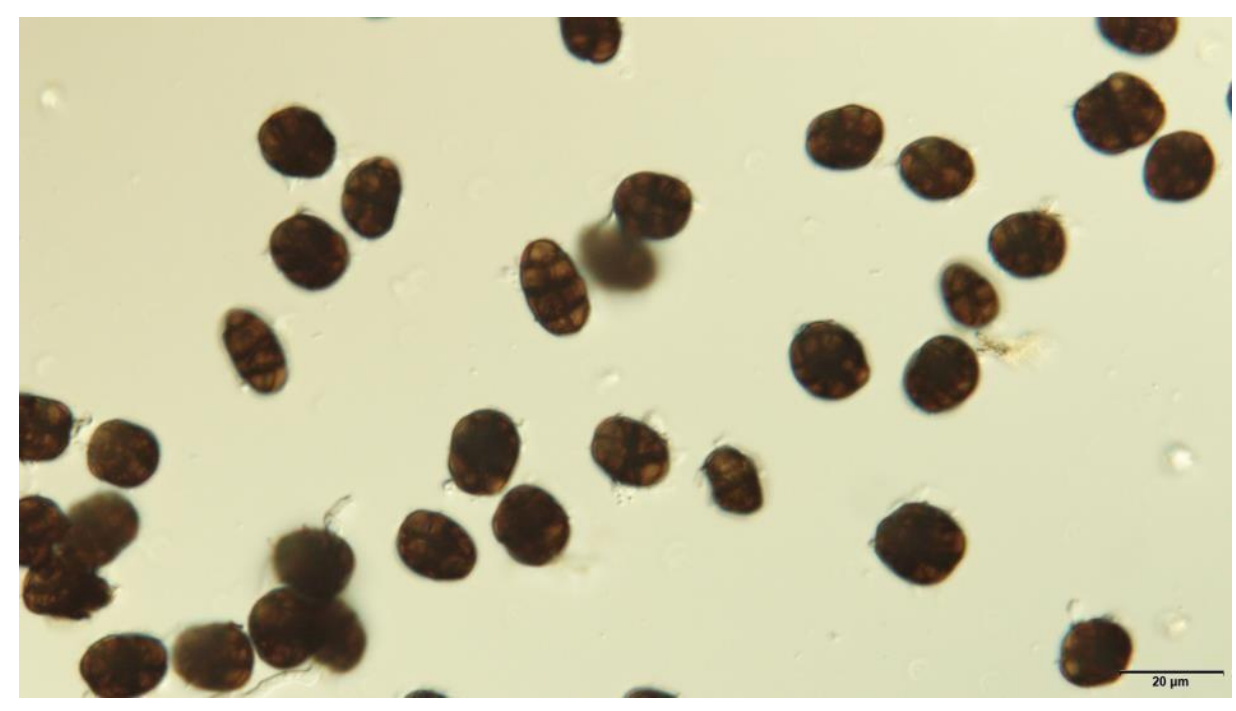

Fig 1. Camarosporium astragalinum conidia.

ellipsoid, muriform, with 2-3 transverse and 1-2 longitudinal septa, continuous or slightly constricted, initially hyaline, later becoming brown to dark-brown at maturity.

Known Distribution: Turkey (this paper), Hungary [19], Caucasus [26], and Turkmenistan [27, 28, 29]

Known Hosts-Fabaceae: Astragalus asciocalyx (this paper), A. caucasicus [26], A. virgatus

[19], A. sp. [29] and A. unifoliolatus [27, 28].

Material Examined:Turkey. Kirşehir: Boztepe, on dead stems of Astragalus asciocalyx , $1335 \mathrm{~m}$ a. s.1., 39 13' 953' 'N, 34 14' 967' ' E, 27/ IV/2013, KE 35.

Comments: According to Saccardo and Trotter [19] conidiomata about $0.5 \mathrm{~mm}$, conidia 14- 18 x 6 $\mu \mathrm{m}$, with 3 transverse and 1-2 not complete longitudinally septa. The specimen KE 35 is morphologically similar to C. astragalinum [19]. However, the studied material has slightly wider and shorter conidia. In the literature, there are no records of $C$. astragalinum on Astragalus asciocalyx. So far, this species was found on three hosts of the Astragalus genus: A. caucasicus [26], A. Virgatus [19], A. sp. [29] and A. unifoliolatus [27, 28]. This is the first record C. astragalinum for Turkey and a new host, milkvetch A. asciocalyx.

Camarosporium cruciatum (Fuckel) Sacc. [Bas. Coniothyrium cruciatum Fuckel, Jb. nassau. Ver. Naturk.23-24: 173 (1870). Homotypic syn: Camarosporium cruciatum (Fuckel) Sacc., Syll. fung. (Abellini) 3: 464 (1884); Camarosporulum cruciatum (Fuckel) Tassi, Bulletin Labor. Orto Bot. de R. Univ. Siena 5: 65 (1902)]. Fig. 2. A-C. 


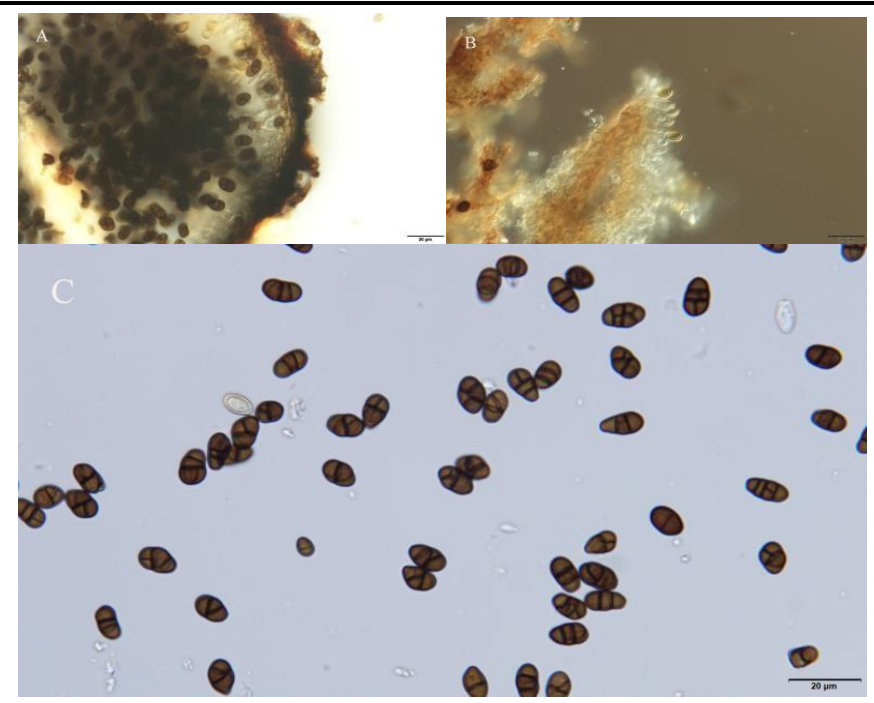

Fig 2. A-C. Camarosporium cruciatum. A. Section of Pycnidium. B. Immatur conidia and conidiogen cells. C. Conidia.

Saprobic on dead branches of Ulmus minor. Sexual Morph: Undetermined.

Asexual Morph: Conidiomata 250-320 $\mu \mathrm{m}$ diam., pycnidial, immersed, erumpent, gregarious, globose, black, with a round pore. Conidia 10-12(-13) $\times(5-) 6-7 \mu \mathrm{m}$., ellipsoid, ovoid, mostly straight, occasionally slightly curved, with 1-3 transverse cruciate and single loculus longitudinally septa, slightly constricted, dark-brown.

Known Distribution: Turkey (this paper), Germany, Italy [15], Turkmenistan [30] and Ukraine [31].

Known Hosts-Betulaceae: Alnus campestris [15]; -Moraceae: Morus alba [30];-- Ulmaceae: Ulmus minor (this paper); [31].

Material Examined: Turkey. Kirşehir: Boztepe, on dead branches of Ulmus minor, $1391 \mathrm{~m}$ a.s.l., $39^{\circ} 12^{\prime} 519^{\prime}$ ' N, 34 12' 965' E, 27/VII/2013, KE 114.

Comments: The collected material were identified as $C$. cruciatum according to Saccardo [15]. In his description, $C$. cruciatum has shorter conidia (6-10 $\mu \mathrm{m}$ diam.) with 1-4 transverse cruciate septa. This is the first record $C$. cruciatum for Turkey.

Camarosporium kirchneri Staritz, in Diedicke, Krypt.-Fl. Brandenburg (Leipzig) 9(4): 680 (1914).

Fig. 3. A-B. Saprobic on dead branches of Prunus divaricata.

Sexual Morph: Undetermined.

Asexual Morph: Conidiomata 350-400 $\mu \mathrm{m}$ diam., pycnidial, immersed, erumpent, scattered or gregarious, globose, dark-brown, with a round pore. Conidia 10-20 × 6-7,5 $\mu \mathrm{m}$., oval, ovoid, oblongellipsoid, with 1-3 transverse and one not complete longitudinal septa, continuous or slightly constricted, brown.

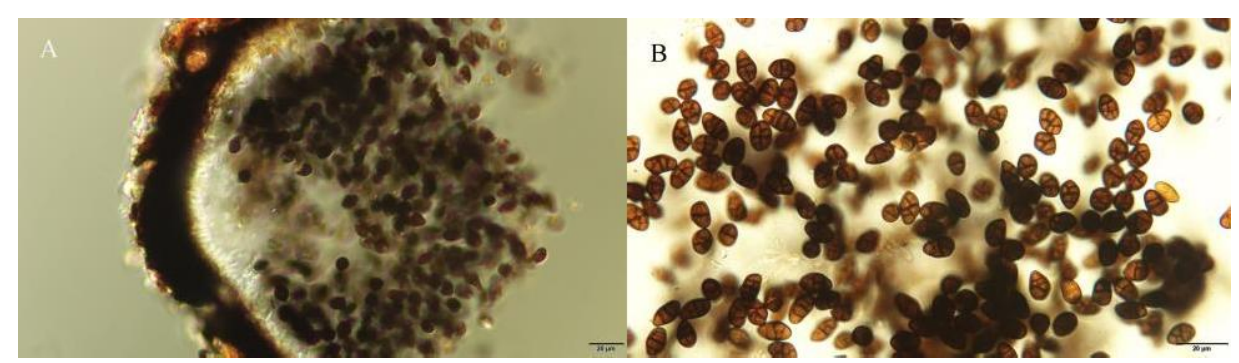

Fig 3. A-B. Camarosporium kirchneri. A. Section of Pycnidium. B. Conidia.

Known Distribution: Turkey (this paper), Germany [20], Kazakhstan [24], Turkmenistan [27], Moldavia [32] and Georgia [33].

Known Hosts-Rosaceae: Prunus divaricata (this paper; [33], P. domestica [20], P. spinosa [24], Armeniaca vulgaris [27] and Cerasus avium, C. vulgaris, Amygdalus communis [32]. 
Material Examined: Turkey. Kirşehir: Boztepe, on dead branches of Prunus divaricata, $1326 \mathrm{~m}$ a.s.1., 39 14'018' ' N, 34 15'077' ' E, 27/IV/2013, KE 244.

Comments: According to Saccardo et al. [20] conidiomata up to $400 \mu \mathrm{m}$ diam., conidia 13-18 $\times 5-7$ $\mu \mathrm{m}, 3$-septate. Conidiomata of Kazakhstan samples on Prunus spinosa is 112-206 $\mu \mathrm{m}$ diam., conidia 8-17 $\times 5-7.5 \mu \mathrm{m}$, with 1-3 transverse and one longitudinal septa [24]. In Moldavia according to description of Popushoj [32] conidiomata 400-500 $\mu \mathrm{m}$, conidia $14.5-17.5 \times 6.5-9.8 \mu \mathrm{m}$, with 3-5 transverse and one longitudinal septa. The conidiomata and conidia of the specimen studied are larger than type species, Kazakhstan and Moldavia samples. This is the first record C. kirchneri for Turkey.

Camarosporium multiforme Schulzer \& Sacc., Hedwigia 23: 110 (1884).Fig. 4. A-C.

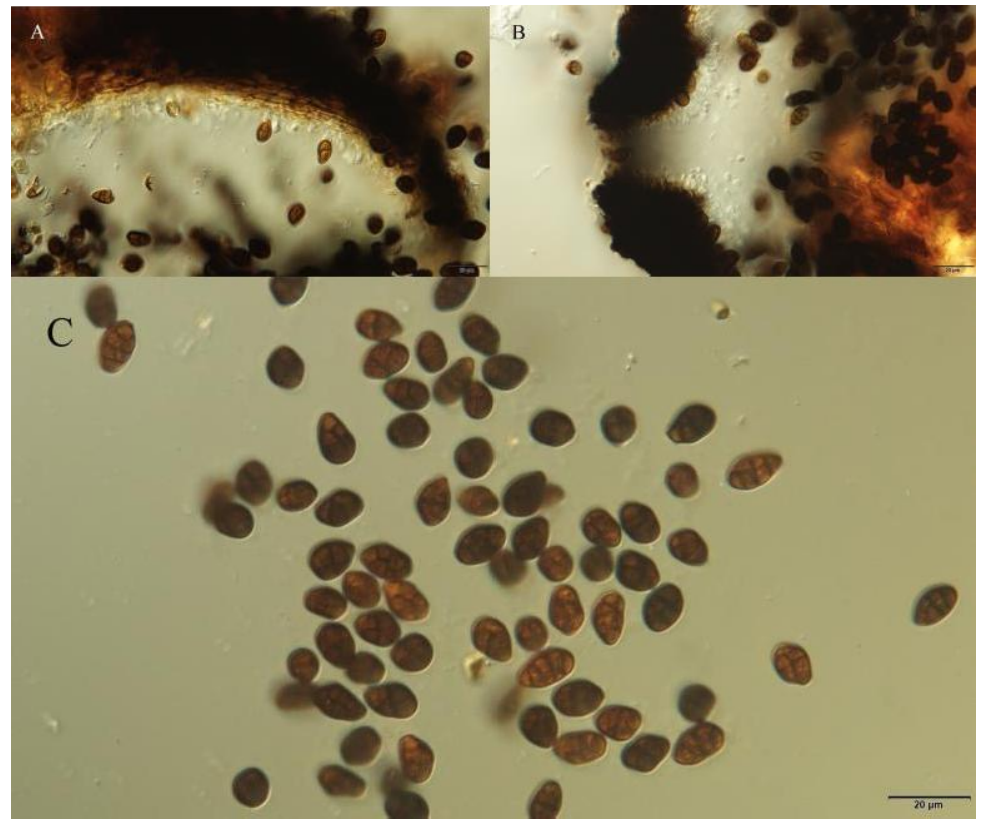

Fig 4. A-C. Camarosporium multiforme. A. Section of Pycnidium, immature conidia and conidiogen cells. B. Section of pycnidial pore. C. Conidia.

Saprobic on dead branches of Crataegus aronia. Sexual Morph: Undetermined.

Asexual Morph: Conidiomata 150-330 $\mu \mathrm{m}$ diam., pycnidial, immersed, then erumpent and almost superficial, scattered or densely gregarious, globoid, black, obtusely papillate, thick- walled. Conidia (11-)12-13(-17.5) × (7-)7.5-9 $\mu \mathrm{m}$., ellipsoid, broadly ellipsoid, ovoid, pyriform, oblong, clavate, with 1-3 transverse cruciate and one complete or not complete cruciate longitudinal septa, continuous or slightly constricted, dark-brown.

Known Distribution: Turkey (this paper), Slovenia [15], Moldavia [32], Turkmenistan [30] and Ukraine [31].

Known Hosts -Rosaceae: Crataegus aronia (this paper), Cydonia vulgaris [15], Pyrus communis [32], Chaenomeles japonica, Malus domestica [30] and Mespilus germanica [31].

Material Examined: Turkey. Kirşehir: Boztepe, ondead branches of Crataegus aronia, $1337 \mathrm{~m}$

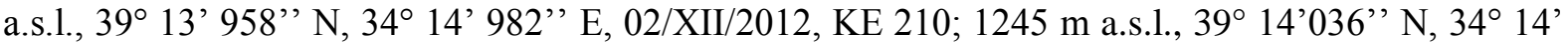
707'’ E, 27/IV/2013, KE 235.

Comments: According to Saccardo [15] conidiomata 100-170 $\mu \mathrm{m}$ diam., conidia 9-12(-18) $\mu \mathrm{m}$ long, with 1-3 transverse and one not complete longitudinal septa. In description of Popushoj [32] conidiomata $200-400 \mu \mathrm{m}$, conidia $15-25 \times 7-11 \mu \mathrm{m}$, with 3-5 transverse and 1-3 longitudinal septa. The specimen collected in Turkey has larger conidiomata and shorter conidia. In the literature $[15,30$, 31, 32] documented this species associated with Cydonia, Chaenomeles, Malus, Mespilus and Pyrus species in Slovenia, Moldavia, Central Asia and Ukraine. There are no records of C. multiforme associated with Crataegus species. This is the first record of $C$. multiphorme for the Turkey and on a new host, the hawthorn $C$. aronia.

Camarosporium polymorphum (De Not.) Sacc., Michelia 1(no. 2): 208 (1878). [Bas. Diplodia 
polymorpha De Not., Micr. Ital., Dec. 4: fig.5 (1842)].Fig. 5. A-B.

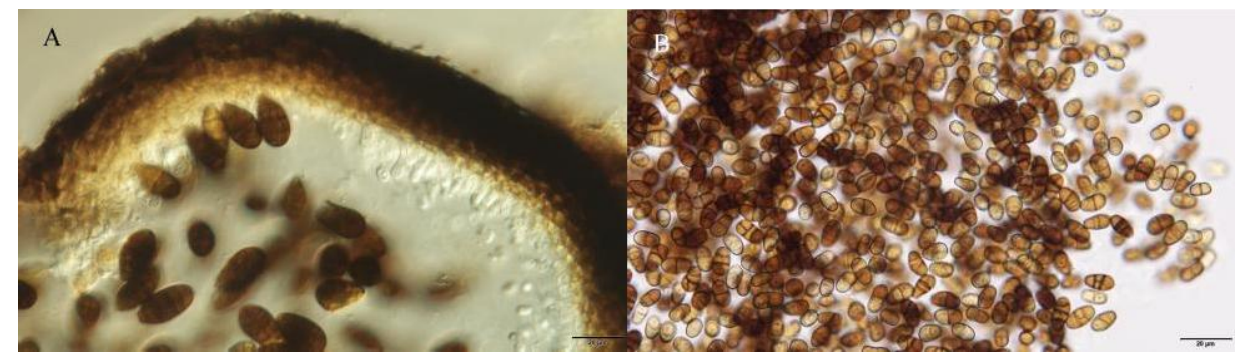

Fig 5. A-B. Camarosporium polymorphum. A. Section of Pycnidium, immature conidia and conidiogen cells. B. Conidia.

Saprobic on dead branches of Lonicera etrusca. Sexual Morph: Undetermined.

Asexual Morph: Conidiomata 180-250 $\mu \mathrm{m}$ diam., pycnidial, scattered, immersed, erumpent, globose, subglobose, papillate, dark-brown. Conidia 10-12.5 × 6-7.5(-8) $\mu \mathrm{m}$, ellipsoid, ovoid, fusiform rounded at both ends, straight, occasionally slightly curved, muriform, with 1-3 transverse and one not complete longitudinal septa, continuous, shining brown.

Known Distribution: Turkey (this paper), Italy [15], Kazakhstan [24], Ukraine [31], Georgia [33], Uzbekistan [34], Kirgizia [35] and Pakistan [36].

Known Hosts - Caprifoliaceae: Lonicera etrusca (this paper), L. xylostei [15], L. semenovii [24], L. tatarica [35], L. sp. [36]; - Oleaceae: Jasminum fruticans [31];-- Rutaceae: Haplophyllum bungei, H.sp. [34], Phellodendron amurense [33], Ruta sp. [15].

Material Examined: Turkey. Kirşehir: Boztepe, on dead branches of Lonicera etrusca,1342 m a.s.l., 39 ${ }^{\circ} 12^{\prime} 830^{\prime \prime}$ N, 34 13 ' 281'’ E, 04/XI/2012, KE 172.

Comments: According to Saccardo [15] conidia $10 \times 8 \mu \mathrm{m}$ with 3-4 transverse septa. In description of Byzova et al. [15] C. polymorphum has conidiomata 70-80 $\mu \mathrm{m}$ diam., conidia 7.5-9 $\times 6-7 \mu \mathrm{m}$, with 1-3 transverse and one not complete longitudinal septa. The Turkish samples differ from the diagnosis of type species in the larger sizes of conidia and smaller number of transverse septa and differ from Kazakhstan samples in larger size of conidiomata and conidia.This is the first record $C$. polymorphum for Turkey, and on a new host, the honeysuckle Lonicera etrusca.

Camarosporium ulmi Ellis \& Dearn., Proc. of the Canad. Inst. 1897, p. 92. [Homotypic syn: Camarosporulum ulmi (Ellis \& Dearn.) Tassi, Bulletin Labor. Orto Bot. de R. Univ. Siena 5: 66 (1902)].Fig. 6. A-C.

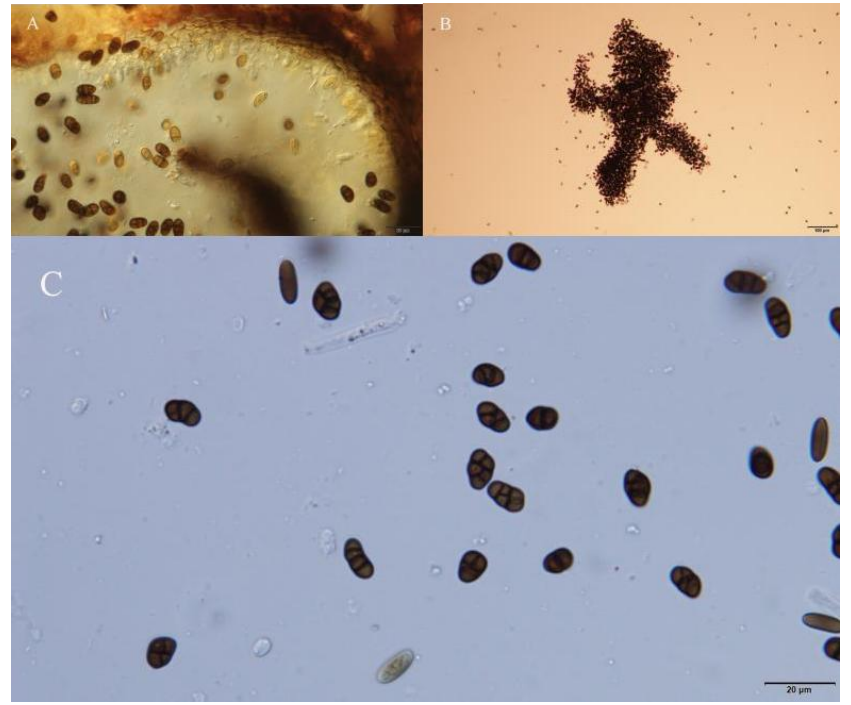

Fig 6. A-C. Camarosporium ulmi. A. Section of Pycnidium, immature conidia and conidiogen cells. B. Mass of conidia as X. C. Conidia.

Saprobic on dead branches of Ulmus minor. Sexual morph: Undetermined.

Asexual morph: Conidiomata 330-350 $\mu \mathrm{m}$ diam., pycnidial, gregarious, immersed, erumpent, 
globose, depressed-globose, black, with circular central ostiole. Conidia 10-12(- 12,5) × 5-8(-9) $\mu \mathrm{m}$, ellipsoid, ovoid, straight, or slightly curved, submuriform, with 1-4 transverse and one not complete longitudinal septa, slightly constricted, dark-brown.

Known Distribution: Turkey (this paper), England [17], Georgia [33] Kirghizia [35] and Canada [37].

Known Hosts - Ulmaceae: Ulmus minor (this paper), $U$. sp. [17, 33, 37] and U. pinnato- ramosa [35].

Material Examined: Turkey. Kirşehir: Boztepe, on dead branches of Ulmus minor, $1391 \mathrm{~m}$ a.s.l., $39^{\circ} 12^{\prime} 519^{\prime \prime} \mathrm{N}, 34^{\circ} 12^{\prime}$ 965' ' E, 27/VII/2013, KE 200.

Comments: According to Saccardo \& Sydow [17] conidiomata about $330 \mu \mathrm{m}$ diam., conidia 12-13 $\times$ 6-8 $\mu \mathrm{m}, 3$-septate, and Mosolova [35] conidiomata of Kirgizian samples 256-358 $\mu \mathrm{m}$., conidia 10-16 $\times 6-10 \mu \mathrm{m}$. The Turkish samples almost similar to the diagnosis of type species. However, the studied material has conidia with 1-3 transverse septa. Morever, conidia of our specimen is shorter then Kirghizian data. This is the first record C. ulmi for Turkey.

The genus Camarosporium are represented with six species: $C$. astragalinum, $C$. cruciatum, $C$. kirchneri, C. multiforme, C. polymorphum, and C. ulmi. These species identified as new records for the Anatolian Peninsula. All species are saprobic on dead stems, twigs or branches of trees and buches, and collected in forest ecosystems. Some morphological characteristics were also deviating from the original descriptions, but because of the lack of molecular data, a relatively conservative and broad species concept was applied instead of naming new species. Future molecular analyses might be helpful to clarify whether different hosts and minor morphological differences justify the separation of new taxa. Our findings demonstrate the importance of field collection and morphological analysis in different localities for fungal biodiversity inventories

A check of the current literature $[7,38,39,40,41,42,43,44,45]$ revealed that 10 Camarosporium species have been reported from different localities in Turkey until the end of 2016. Nevertheless, a unified checklist of this genus does not exist. This study could be helpful in compiling the general checklist of Camarosporium species of Turkey. With the addition of new records the total number of Turkish Camarosporium species increased to 16. On the other hand, more than 500 species of Camarosporium have been recorded worldwide

\section{CONClusion}

Camarosporium astragalinum, C. cruciatum, C. kirchneri, C. multiforme, C. polymorphum and C. ulmi are first reports from the Anatolian Peninsula.

\section{REFERENCES}

[1] Schulzer, S. (1870). Mykologische Beitrage. Verhandlungen der Zoologisch-Botanischen Gesellschaft Wien. 20, 635-658.

[2] Index Fungorum (2017). http://www.indexfungorum.org. Accessed 5 June 2017.

[3] Sutton, B.C. (1980). The Coelomycetes. Fungi imperfecti with pycnidia, acervuli and stromata. CABI Publishing, Kew, Surrey, England.

[4] Farr, D.F., Rossman A.E. (2014). Fungal databases. Systematic Mycology and Microbiology Laboratory, ARS, USDA. Retrieved May 18. fromhttp://nt.ars- grin.gov/fungaldatabases/.

[5] Zachos, D.G., Tzavella-Klonari K., Roubos J.C. (1974). A disease of pistachio tree (Pistacia vera L.) caused by the fungus Camarosporium pistaciae n. sp. Ann. Inst. Phytopathol. Benaki 11, 5358.

[6] Holevas, C.D., Chitzanidis, A., Pappas, A.C., Tzamos, E.C., Elena, K. et al. (2000). Disease agents of cultivated plants observed in Greece from 1981 to 1990. Benaki Phytopathol. Inst., Kiphissia, Athens. 19, 1-96.

[7] Hüseyinov, E. (2000). New records of microfungi for Turkey. Israel Journal of Plant Sciences 48(1), 75-78.

[8] Hüseyin, E. , Yıldızbaş M. (2005). Some micromycetes on oak (Quercus) in Karaman Province of Turkey. Proceedings of the XVI Symposium of Mycologists and Lichenologists of Baltic States, Latvia, Cesis. P. 69-75. 
[9] Taylor, J.E., Crous P.W., Swart L. (2001). Foliicolous and caulicolous fungi associated with Proteaceae cultivated in California. Mycotaxon 78: 75-103.

[10] Wijayawardene, N.N., Bhat D.J., Hyde K.D., Camporesi E., Wikee S. et al. (2014). Camarosporium sensu stricto in Pleosporinae, Pleosporales with two new Species. Phytotaxa 183(1), 16-26.

[11] Wijayawardene, N.N., Hyde K.D., Bhat D.J., Camporesi E., Schumacher R.K. et al. (2014). Camarosporium-like species are polyphyletic in Pleosporales; introducing Paracamarosporium and Pseudocamarosporium gen. nov. in Montagnulaceae. Cryptogamie, Mycologie 35 (2), 177198.

[12] Crous P. W., Groenewald J. Z. (2017).The Genera of Fungi - G 4: Camarosporium and Dothiora. IMA Fungi 8(1), 131-152.

[13] Hamzaoğlu, E. (1996). Flora of Kervansaray Mountain (Kırşehir). The Herb. J. of Syst. Bot. $3(1), 1-24$.

[14] Davis, P.H. (1965-1985). Flora of Turkey and East Aegean Islands. Edinburg Univ. Press. Edinburgh.

[15] Saccardo, P.A. (1884). Sylloge Fungorum. Vol. 3. Padova.

[16] Saccardo, P.A. (1886). Sylloge Fungorum. Vol. 4. Padova.

[17] Saccardo, P.A., Sydow P. (1899). Sylloge Fungorum. Vol.14 (2). Patavii.

[18] Saccardo, P.A., Saccardo D. (1906). Sylloge Fungorum. Vol. 18. Patavii.

[19] Saccardo, P.A., Trotter A. (1913). SyllogeFungorum. Vol. 22(2). Patavii.

[20] Saccardo, P.A., Saccardo, D., Traverso, J.B., Trotter, A. (1931). Sylloge Fungorum . Vol. 25. (Supplementum Universale Pars X). Pergola.

[21] Allescher, A. (1901). In Rabenhorst's Kryptogamenflora von Deutschland, Oesterreich und Schweiz. Bd. 1, Abt. VI. Fungi imperfecti. Leipzig.

[22] Allescher, A. (1903). In Rabenhorst's Kryptogamenflora von Deutschland, Oesterreich und Schweiz. Bd. 1, Abt. VII. Fungi imperfecti. Leipzig.

[23] Grove, W.B. (1937). British stem- and leaf fungi (Coelomycetes). Vol. II. Sphaeropsidales. Cambridge Univ. Press. London.

[24] Byzova, Z.M., Vasyagina, M.P., Deeva, N.G., Kalymbetov, B.K., Pisareva, N.F. et al. (1970). Flora of Cryptogamic Plants of Kazakhstan. V. Fungi Imperfecti (Deuteromycetes), 3. Sferopsidal'nye - Sphaeropsidales. Nauka, Alma-Ata. (In Russian).

[25] Kirk, P.M., Ansell, A.E. (1992). Authors of fungal names. Index of fungi supplement. CAB International, Wallingford.

[26] Jaczewski, A.A. (1917). Opredelitel' gribov. T. 2. Nesovershennye griby. Petrograd. (In Russian).

[27] Koshkelova, E.N., Frolov, I.P., Dzhuraeva, Z. (1970). Mycoflora of Badkhyz, Karabil and southern part of Murgab oasis. Ylym, Ashkhabad. (In Russian).

[28] Koshkelova, E.N., Frolov I.P., Orlov, V.A., Bezukhova, Z.P., Kerbabaeva A.A. et al. (1983). Mycoflora oases of Northern Turkmenistan. Ylym, Ashkhabad. (In Russian).

[29] Frolov I.P., Koshkelova, E.N., Orlov, V.A., Bezukhova, Z.P. (1979). Mycoflora of Kyupendag, Minor and Greater Balkhans. Ylym, Ashkhabad. (In Russian).

[30] Koshkelova, E.N., Frolov, I.P. (1973). Mycroflora of Kopet-Dag lowland and Central Karakum (micromycetes). Ylym, Ashkhabad (in Russian).

[31] Dudka, I.O., Heluta, V.P., Y.Y. Tykhonenko, Y.Y., Andrianova, T.V., Hayova, V.P. et al. (2004). Fungi of the Crimean Peninsula. M.G. Kholodny Institute of Botany, National Academy of Sciences of Ukraine, Kyiv: Phytosociocentre. (In Ukrainian).

[32] Popushoj, I.S. (1971). Mycoflora of fruit trees in USSR. "Nauka", Moskowa. (In Russian). [33] Melia, M.S., I.A. Shavliashvili, I.A., Mshvidobadze, L.V. (1987). Fungi on trees and shrubs of Georgia forests. "Sabchota Sakartvelo". Tbilisi. (In Russian).

[33] Gaponenko, N.I. (1965) Survey of the Fungi of Bukhara. Akad. Sci. Uzbekh. (In Russian). [35] Mosolova, S.N. (1987). Micromycetes of trees and shrubs of the Chui valley and the northern slope of the Kirghiz mountain range. Ilim, Frunze. (In Russian). 
[34] Ahmad, S., Igbal, S.H., A.N. Khalid, A.N. (1997). Fungi of Pakistan. Sultan Ahmad Mycological Society of Pakistan.

[35] Cash, E.K.(1952). A record of the fungi named by J.B. Ellis (Part 1). U.S.D.A. Special Publ. 2, $1-165$.

[36] Göbelez, M. (1964). La Mycoflore de Turguie. II. Mycopathologia et Mycologia Applicata 23(1), 47-67.

[37] Hüseyin, E. (2004). Xylotrophic of Ihlara Valley (Kapadokya, Turkey). Proceedings of the International Scientific Conference. Minsk. P. 72-75.

[38] Hüseyin, E., Selçuk, F. (2014). Coelomycetous fungi in several forest ecosystems of Black Sea provinces of Turkey. Agriculture and Forestry 60(2), 19-32.

[39] Hüseyinov, E., Selçuk, F. (2001). Cotribution to study of mycoflora of Turkey. I. Coelomycetes of orders Melanconiales and Sphaeropsidales on forest trees and shrubs in the Black sea coast (Rize and Trabzon Provinces). Mikologia i Fitopatologia 35(1), 28-33.

[40] Selçuk, F., Hüseyin, E. (2014). New records of microfungi from Mountain Strandzha in Turkey (south-eastern Europe). II. Mikologiya i Fitopatologiya 48(3), 202-208.

[41] Selçuk, F., Hüseyin, E., Bitmiş, K. (2003). Some materials on mitosporic fungi from Turkey. II. Coelomycetes. [Kai kurie duomenys apie Turkijos mitosporinius grybus. II. Coelomycetes]. Botanica Lithuanica 9(2), 161-170.

[42] Mel'nik, V.A., Hüseyin, E., Selçuk, F. (2004). Contribution to the studying of micromycetes in several Black Sea Provinces of Turkey. Academia Scientarum Rossica, Institutum Botanicum Nomine V.L. Komarov, Novitates Systematicae Plantarum non Vascularum, Nauka, Petropolis, 37, 133-148.

[43] Hüseyin, E., Selçuk, F., Ekici K. (2015). Some micromycetes on trees and bushes in forests of Boztepe District Kirsehir Province (Turkey). Problems of Forest Phytopathology and Mycology. Materials of IX International Conference. October 19-24, 2015. Minsk - Moscow Petrozavodsk. P. 235-238.

Citation: E. Huseyin et al. "Species of Camarosporium on Forest Trees and Shrubs New Reports from Anatolian Peninsula ", International Journal of forestry and Horticulture (IJFH), vol. 3, no. 2, p. 8, 2017, http://dx.doi.org/10.20431/2454-9487.0302001.

Copyright: () 2017 Authors. This is an open-access article distributed under the terms of the Creative Commons Attribution License, which permits unrestricted use, distribution, and reproduction in any medium, provided the original author and source are credited. 